\title{
Impact of temperature humidity index (THI) on physiological responses and milk yield of Tharparkar and Karan Fries cows exposed to controlled environment
}

\author{
S.V. SINGH*, YOGENDRA KUMAR and SUNIL KUMAR \\ Animal Physiology Division, ICAR-National Dairy Research Institute, Karnal, Haryana - 132001 \\ *Corresponding author: sohanvir2011@gmail.com
}

\begin{abstract}
Tharparkar and Karan Fries cows were exposed to $25^{\circ} \mathrm{C}, 35^{\circ} \mathrm{C}$ and $42^{\circ} \mathrm{C}$ with relative humidity of $50 \pm 5 \%$, corresponding to $\mathrm{THI}$ of $72.2,85.3$ and 91.0 , respectively for three hours continuously for three days consecutively in the control climatic chamber. At THI of 91.0 , physiological responses i.e. RR/ min, $\mathrm{PR} / \mathrm{min}$ and $\mathrm{RT}\left({ }^{\circ} \mathrm{F}\right)$ increased by 14,13 , and 1.18 in Tharparkar and 23, 14 and 2.98 in Karan Fries cows, respectively over pre exposure values. At THI of 91.0, the surface body temperature was increased over THI 72.2 by 5.21 to $7.52^{\circ} \mathrm{C}$ in Tharparkar and 7.45 to $8.42^{\circ} \mathrm{C}$ in Karan Fries cows. Skin blood flow of Karan Fries cows was increased by 4.98, 4.15 and 3.95 PU at THI 85.3 and 6.84, 9.18 and 8.04 PU at $91 \mathrm{THI}$ over the pre exposure values of respective THI at dorsal, ventral and ear part of body, respectively. The decrease in milk yield was calculated in the THI range of 72.2 - 91.0, the milk yield was decrease (per unit increase in THI) by $135.11 \mathrm{ml}$ in Karan Fries and $51.60 \mathrm{ml}$ in Tharparkar cows. The results of the study clearly indicated the more sensitivity of Karan Fries compared to Tharparkar cows at higher THI. Therefore, Karan Fries cows needs protection from extreme heat for sustained production performance.
\end{abstract}

Key words: Surface temperature, blood flow, milk yield, Tharparkar, Karan Fries, THI.

In India, livestock plays a crucial role in the socioeconomic development and is the major source of livelihood. Due to fast urbanization in developing countries, demand for livestock products is increasing rapidly. The major limitation to livestock production system in tropical countries including India is heat stress/ climate change. Global mean temperature of the earth has increased by $0.8^{\circ} \mathrm{C}$ over the past century and is projected to raise $1.5-4.8^{\circ} \mathrm{C}$ up to the end of this century (IPCC, 2014). Significant differences exist in heat tolerance of Bos indicus cattle exhibit better resistance to environmental stressors relative to Bos taurus. Indian native breed, Sahiwal and cross-breed, Frieswal were found to have different heat stress responses in-terms of body rectal temperature, respiration rates and production parameters under stress conditions (Sajjanar et al., 2015). Thermoregulation is a process in which ambient conditions provokes the cascade of responses to maintain body temperature within the narrow range necessary for optimum physiological function of animals. Animals' increases blood flow to the periphery and increase evaporative heat loss through sweating and panting to increase the heat exchange with the environment depending upon the humidity levels in the surrounding air. Hyperthermia results when body temperature increases above normal range despite these adjustments. Quantitative measures of the thermal environment and the animals' responses to heat stress are needed to assess thermal tolerance. Generally used measures of the thermal environment are temperature, humidity, solar radiation, and wind speed, whereas coat characteristics, core body temperature, skin temperature, respiration rate, and sweating rate describe thermal environment from an animal perspective. Keeping in view the above facts in mind, present study was designed to compare the heat tolerance of indigenous (Tharparkar) and crossbred (Tharparkar x Holstein Friesian) cattle under different temperature humidity indices in the controlled climatic chamber.

\section{MATERIALS AND METHODS}

Five each of lactating Tharparkar and Karan Fries cows were selected from the livestock research centre of ICARNDRI, Karnal for the study. Karnal is situated at an altitude of $250 \mathrm{~m}$ above mean sea level, latitude and longitude position being $29^{\circ} 42^{\prime \prime} \mathrm{N}$ and $79^{\circ} 54^{\prime \prime} \mathrm{E}$, respectively. The maximum ambient temperature during summer goes $>42^{\circ} \mathrm{C}$ and minimum temperature during winter come down $<2^{\circ} \mathrm{C}$ with a diurnal variation of $15-20^{\circ} \mathrm{C}$ (Maibum et al., 2018).

All the animals were fed as per the NRC (2001), ration consisting of concentrate mixture and roughages (berseem, maize, sorghum fodder etc). Concentrate mixture consisted of maize $28 \%$, groundnut cake $10 \%$, mustard cake $13 \%$, wheat bran $15 \%$, rice polish $11 \%$, soybean deoiled $15 \%$, bajra $5 \%$, mineral mixture $2 \%$ and common salt $1 \%$ with approx. $16 \%$ 
$\mathrm{CP}$ and $70 \%$ TDN. Freshwater was available for drinking round the clock.

These animals were exposed to climatic chambers at different combination of temperature i.e. $25^{\circ} \mathrm{C}, 35^{\circ} \mathrm{C}$ and $42^{\circ} \mathrm{C}$ with a relative humidity of $50 \pm 5 \%$. The corresponding THI of these combinations of temperature and humidity were 72.2 , 85.3 and 91 respectively. These three THI were taken purposefully i.e. 72.2- comfortable, 85.3 - mild stress and 91severe stress condition. Experimental animals were exposed individually for three hours continuously at different climatic chamber conditions for three days consecutively. Physiological parameters in terms of respiration rate (RR), pulse rate $(\mathrm{PR})$ and rectal temperature were monitored by recording flank movements/min, palpation of coccygeal artery/ min and by using digital thermometer respectively.

Peripheral blood flow of experimental animals were recorded at dorsal, ventral part and ear in climatic chamber at different exposure conditions using Perimed Multichannel Laser Doppler system (Perimed AB, Jarfalla, Sweden) with skin perfusion probe 408 . The values of blood flow were expressed as Perfusion Units (P.U). Body surface temperature of all the experimental animals were also recorded using noncontact laser thermometer, keeping the thermometer 5-6 cm. away from the body surface of the animals.

The physiological parameters (RR, PR and RT), peripheral blood flow and body surface temperature at different anatomical sites (dorsal, ventral part and ear) of Tharparkar and Karan Fries cows were recorded prior to exposure in climatic chamber and after end of three hours of exposure at different exposure conditions/ THI.

Milk yield of all the experimental animals (Tharparkar and Karan Fries cows) were recorded 15 days prior to the actual experiment and during the experiment period.

Statistical analysis of the data was performed using the SPSS 16.0 software programme. The values are expressed in terms of mean \pm SEM and means were compared for significance.

\section{Ethical permission}

The experiment was approved by the Institutional Animal Ethics Committee (IAEC) established as per the article number 13 of the committee for the purpose of control and supervision of experiments on animals (CPCSEA) rules laid down by the Government of India.

\section{RESULTS AND DISCUSSION}

\section{Physiological responses}

The Physiological responses i.e. respiration rate (RR), pulse rate $(\mathrm{PR})$ and rectal temperature $(\mathrm{ST})$ were higher $(\mathrm{P}<0.05)$ at higher THI, $91\left(42^{\circ} \mathrm{C}\right.$ and $\left.50 \pm 5 \% \mathrm{RH}\right)$ followed by $85.3\left(35^{\circ} \mathrm{C}\right.$ and $\left.50 \pm 5 \% \mathrm{RH}\right)$ and $72.2\left(25^{\circ} \mathrm{C}\right.$ and $\left.50 \pm 5 \% \mathrm{RH}\right)$ in both Tharparkar and Karan Fries cows (Table 1). The magnitude of increase in these physiological parameters was higher in Karan Fries than Tharparkar cows (Table 1). The increase in $\mathrm{RR} / \mathrm{min}, \mathrm{PR} / \mathrm{min}$ and $\mathrm{RT}^{\circ} \mathrm{F}$ was 6,8 and 0.41 in Tharparkar (Table 1) and 10, 8 and 1.06 in Karan Fries cows (Table 1) respectively over pre exposure values after three hours of exposure at THI of 85.3. Similarly the magnitude of increase in respective physiological parameters over pre exposure values was further higher after three hours of exposure at THI (91) i.e. 14, 14, and 1.18 in Tharparkar and 23, 14 and 2.98 in Karan Fries cows (Table 1). The results of present study is in accordance with those of Velagala and Singh (2018) who reported significantly higher physiological responses during hot humid season and in Karan Fries cattle compared to autumn and Tharparkar cattle respectively during exposure under natural ambient conditions. Singh and Upadhyay (2009) also reported higher respiration rate and rectal temperature in Karan Fries (Tharparkar $\times$ Holstein Friesian) than Sahiwal cattle during heat stress. The deviations in physiological responses depend upon the change in ambient conditions and are important to cope up the animals under adverse climatic conditions. Stressors of some systems are detectable as modifications of rectal temperature, respiration or heart rates, which are the valid index of social stress/discomfort in large animals (Guyton and Hall 2006). The higher magnitude of physiological responses in Karan Fries than Tharparkar cows indicates the sensitivity of this breed to heat stress (Table 1). Gaughan et al. (2000) also reported a lower respiration rate under heat stress as an indicator of lesser discomfort in cattle. Under control climatic conditions at $44^{\circ} \mathrm{C}$ in climatic chamber the RR, RT, PR and ST were recorded higher in Karan Fries than Tharparkar cattle (Bhan et al., 2012, 2013). THI and ambient temperature showed positive correlation with Physiological responses (Singh and Upadhyay, 2009).

\section{Surface body temperature}

Surface body temperature at different anatomical sites before and after exposure at different exposures conditions are presented in Table 2. The normal surface body temperature at 
Table 1: Effect of different exposure conditions/ THI on physiological responses of Karan Fries and Tharparkar cows exposed in climatic chamber

\begin{tabular}{|c|c|c|c|c|c|c|c|}
\hline Breed & Parameters & \multicolumn{2}{|c|}{ THI 72.2} & \multicolumn{2}{|c|}{ THI 85.3} & \multicolumn{2}{|c|}{ THI 91.0} \\
\hline \multirow{3}{*}{ 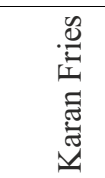 } & Respiration rate/ min & $29.41^{\mathrm{a}} \pm 0.82$ & $32.58^{\mathrm{a}} \pm 0.63$ & $29.91^{\mathrm{a}} \pm 0.55$ & $39.5^{b} \pm 10.00$ & $31.08^{\mathrm{a}} \pm 0.67$ & $54.41^{b} \pm 3.32$ \\
\hline & Pulse rate/min & $71.5^{\mathrm{a}} \pm 1.35$ & $75.5^{\mathrm{a}} \pm 2.43$ & $74.33 \mathrm{a} \pm 1.26$ & $82.16^{\mathrm{b}} \pm 8.00$ & $76.50^{\mathrm{a}} \pm 1.26$ & $91.00^{\mathrm{b}} \pm 4.00$ \\
\hline & Rectal temperature $\left({ }^{\circ} \mathrm{F}\right)$ & $101.13^{\mathrm{a}} \pm 0.11$ & $101.52^{\mathrm{a}} \pm 0.23$ & $100.84^{\mathrm{a}} \pm 0.04$ & $101.90^{\mathrm{b}} \pm 1.06$ & $100.49^{\mathrm{a}} \pm 0.28$ & $103.47^{\mathrm{b}} \pm 2.98$ \\
\hline \multirow{2}{*}{ 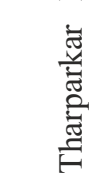 } & Pulse rate/min & $74.87^{\mathrm{a}} \pm 2.00$ & $72.00^{\mathrm{a}} \pm 1.16$ & $73.66^{\mathrm{a}} \pm 1.38$ & $82.03^{\mathrm{b}} \pm 8.00$ & $75.16^{\mathrm{a}} \pm 1.75$ & $88.50^{\mathrm{b}} \pm 6.00$ \\
\hline & Rectal temperature $\left({ }^{\circ} \mathrm{F}\right)$ & $101.95^{\mathrm{a}} \pm 0.11$ & $101.04^{\mathrm{a}} \pm 0.41$ & $101.65^{\mathrm{a}} \pm 0.31$ & $102.06^{\mathrm{b}} \pm 0.41$ & $101.59^{\mathrm{a}} \pm 0.20$ & $102.77^{\mathrm{b}} \pm 1.18$ \\
\hline
\end{tabular}

- Different superscript $(a, b)$ in a row at particular THI indicate significant $(\mathrm{P}<0.05)$ difference

comfortable THI (72.2) at different body parts varied from $31.85^{\circ} \mathrm{C} \pm 0.75$ to $35.23^{\circ} \mathrm{C} \pm 0.29$ in Karan Fries (Table 2) and from $26.39^{\circ} \mathrm{C} \pm 0.02$ to $35.94^{\circ} \mathrm{C} \pm 0.43$ in Tharparkar cows (Table 2). Cardoso et al. (2016) also reported the similar range of body surface temperature in Curraleiro Pe-Duro, Pantaneiro and Nelore Cattle. Surface body temperature increased at different anatomical sites (Dorsal, ventral and ear) with the increase of THI (Table 2). The increase in surface body temperature at THI 85.3 varied from 3.68 to $5.61^{\circ} \mathrm{C}$ in Tharparkar and 4.77 to $5.69^{\circ} \mathrm{C}$ in Karan Fries cows. At higher THI i.e. 91, the surface body temperature was further increased and the magnitude of increase varied 5.21 to $7.52^{\circ} \mathrm{C}$ in Tharparkar and 7.45 to $8.42^{\circ} \mathrm{C}$ in Karan Fries cows. Similar to physiological parameters, $\mathrm{ST}$ at all the anatomical sites increased significantly $(\mathrm{P}<0.01)$ at 35 and $42^{\circ} \mathrm{C}$ temperature exposure over $25^{\circ} \mathrm{C}$. The results indicated lower ears temperature at comfortable THI (72.2) than higher THI (85.3 and 91) and the magnitude of increase in ear temperature at higher THI was significantly $(\mathrm{P}<0.05)$ higher in both the breeds of cattle. Lower surface temperature of body extremities were also reported in cattle by Singh and Singh (2006) and Kotrba et al. (2007). The increase in ear temperature was 5.61 and $5.69^{\circ} \mathrm{C}$ at THI of 85.3 and 7.52 and $8.42^{\circ} \mathrm{C}$ at THI of 91 in Tharparkar and Karan Fries cows respectively. Results clearly indicated higher magnitude of increase in ear surface temperature at higher THI and in Karan Fries cows than lower THI and Tharparkar. The results of the present study is in accordance to those of Kumar et al. (2017) who reported an increase in surface body temperature in crossbred cattle. Roberto and De Souza (2014) reported that ST can be used as an indicator of animal welfare. During the study, heat stress (THI 85.3) and hyperthermia (THI 91) like situation were simulated in controlled climatic chamber to record the changes in the $\mathrm{ST}$ at different anatomical sites and to correlate them with other physiological parameters. The adverse effect of heat stress on skin surface temperature is well known (Church et al., 2014) and different body parts have varied ability to dissipate heat (Vaidya et al., 2012). During the present study the variation in surface temperature at different anatomical sites were observed. Hoffmann et al. (2013) also found the variation in ST at different body sites with the change in the ambient temperature. The higher surface temperature at head region was also observed by Singh and Singh (2006) in crossbred cattle.

\section{Peripheral blood flow}

The blood flow at different parts of body during different exposure conditions in Tharparkar and Karan Fries cows are depicted in Table 3. During comfortable THI (72.2), the mean peripheral blood flow varied from $17.72 \pm 0.05 \mathrm{PU}$ at ear to $23.93 \pm 3.03 \mathrm{PU}$ at dorsal part in Tharparkar cows (Table $3)$. Whereas the respective values in Karan Fries varied from $13.33 \pm 0.39$ at ear to $15.79 \pm 0.65 \mathrm{PU}$ at ventral part (Table 3 ). When these cows were exposed to higher exposure conditions $\left(35^{\circ} \mathrm{C}\right.$ and $50 \pm 5 \% \mathrm{RH}$ and $42^{\circ} \mathrm{C}$ and $50 \pm 5 \%$ ) in climatic chamber, the initial blood flow was higher $(\mathrm{P}<0.05)$ in Tharparkar than Karan Fries cows (Table 3). Skin blood flow was increased by 4.98, 4.15 and 3.95 PU at THI 85.3 and 6.84, 9.18 and $8.04 \mathrm{PU}$ at $91 \mathrm{THI}$ over their pre-exposure values in Karan Fries cows at dorsal, ventral and ear part of body, respectively. The magnitude of skin blood flow was higher in Tharparkar compared to Karan Fries cows, even though the difference between pre exposure and after exposure was more in Karan Fries cows being lower values during pre exposure in Karan Fries cows. The results of the present study are in accordance to those of Singh et al. (2014) and Marai et al. (2007) who reported increase in blood flow from the core to the surface with increase in ambient temperature in order to 
Table 2: Effect of different exposure conditions THI on body surface temperature $\left({ }^{\circ} \mathrm{C}\right)$ at different anatomical sites of Karan Fries and Tharparkar heifers exposed in climatic chamber

\begin{tabular}{|c|c|c|c|c|c|c|c|}
\hline \multirow{2}{*}{ Breed } & \multirow{2}{*}{ Parameters } & \multicolumn{2}{|c|}{ THI 72.2} & \multicolumn{2}{|c|}{ THI 85.3} & \multicolumn{2}{|c|}{ THI 91.0} \\
\hline & & Before & $\overline{\text { After }}$ & Before & $\overline{\text { After }}$ & Before & After \\
\hline \multirow{3}{*}{ 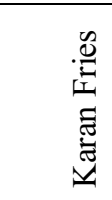 } & Dorsal & $34.47^{\mathrm{a}} \pm 0.74$ & $35.23^{\mathrm{a}} \pm 0.29$ & $34.85^{\mathrm{a}} \pm 1.25$ & $40.31^{b} \pm 5.46$ & $35.36^{\mathrm{a}} \pm 1.16$ & $42.86^{b} \pm 2.50$ \\
\hline & Ventral & $34.95^{\mathrm{a}} \pm 0.25$ & $34.76^{\mathrm{a}} \pm 0.32$ & $35.10^{\mathrm{a}} \pm 0.77$ & $39.87^{b} \pm 1.72$ & $34.70^{\mathrm{a}} \pm 1.20$ & $42.15^{\mathrm{b}} \pm 2.45$ \\
\hline & Ear & $31.85^{\mathrm{a}} \pm 0.75$ & $32.87^{\mathrm{a}} \pm 0.39$ & $33.09^{\mathrm{a}} \pm 1.39$ & $38.78^{b} \pm 2.69$ & $32.68^{\mathrm{a}} \pm 1.30$ & $41.10^{\mathrm{b}} \pm 3.42$ \\
\hline \multirow{3}{*}{ 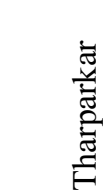 } & Dorsal & $35.94^{\mathrm{a}} \pm 0.43$ & $32.41^{\mathrm{a}} \pm 0.45$ & $35.62^{\mathrm{a}} \pm 1.05$ & $39.30^{\mathrm{b}} \pm 1.68$ & $36.02^{\mathrm{a}} \pm 0.68$ & $41.50^{\mathrm{b}} \pm 1.48$ \\
\hline & Ventral & $35.16^{\mathrm{a}} \pm 0.15$ & $32.16^{\mathrm{a}} \pm 0.36$ & $34.98^{\mathrm{a}} \pm 1.52$ & $39.44^{b} \pm 2.46$ & $35.93^{\mathrm{a}} \pm 0.97$ & $41.14^{\mathrm{b}} \pm 2.21$ \\
\hline & Ear & $32.37^{\mathrm{a}} \pm 0.70$ & $26.39^{\mathrm{b}} \pm 0.02$ & $33.25^{\mathrm{a}} \pm 1.51$ & $38.86^{\mathrm{b}} \pm 2.61$ & $33.81^{\mathrm{a}} \pm 0.90$ & $41.33^{\mathrm{b}} \pm 1.52$ \\
\hline
\end{tabular}

- Different superscript $(\mathrm{a}, \mathrm{b})$ in a row at particular THI indicate significant $(\mathrm{P}<0.05)$ difference

Table 3: Effect of different exposure conditions THI on skin blood flow (PU) at different anatomical sites of Karan Fries and Tharparkar heifers exposed to climatic chamber

\begin{tabular}{|c|c|c|c|c|c|c|c|}
\hline \multirow[t]{2}{*}{ Breed } & \multirow[t]{2}{*}{ Parameters } & \multicolumn{2}{|c|}{ THI 72.2} & \multicolumn{2}{|c|}{ THI 85.3} & \multicolumn{2}{|c|}{ THI 91.0} \\
\hline & & Before & After & Before & After & Before & After \\
\hline \multirow{3}{*}{ 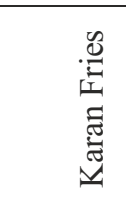 } & Dorsal & $14.27^{\mathrm{a}} \pm 0.64$ & $15.33^{\mathrm{a}} \pm 0.43$ & $15.88^{\mathrm{a}} \pm 0.36$ & $20.86^{\mathrm{b}} \pm 0.46$ & $15.88_{\mathrm{a}} \pm 0.40$ & $22.72^{\mathrm{b}} \pm 0.57$ \\
\hline & Ventral & $14.77^{\mathrm{a}} \pm 0.31$ & $15.79^{\mathrm{a}} \pm 0.65$ & $16.26^{\mathrm{a}} \pm 1.01$ & $20.41^{b} \pm 0.63$ & $16.04^{\mathrm{a}} \pm 0.64$ & $25.22^{\mathrm{b}} \pm 0.47$ \\
\hline & Ear & $13.33^{\mathrm{a}} \pm 0.39$ & $14.33^{\mathrm{a}} \pm 0.48$ & $14.80^{\mathrm{a}} \pm 0.61$ & $18.75^{b} \pm 0.72$ & $15.09^{\mathrm{a}} \pm 0.59$ & $23.13^{\mathrm{b}} \pm 0.48$ \\
\hline \multirow{3}{*}{ 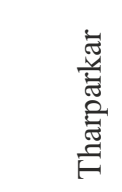 } & Dorsal & $21.99^{\mathrm{a}} \pm 3.24$ & $23.93^{\mathrm{a}} \pm 3.03$ & $21.98^{\mathrm{a}} \pm 2.11$ & $27.83^{\mathrm{b}} \pm 1.17$ & $23.33^{\mathrm{a}} \pm 2.87$ & $28.42^{\mathrm{b}} \pm 0.84$ \\
\hline & Ventral & $20.06^{\mathrm{a}} \pm 2.37$ & $22.57^{\mathrm{a}} \pm 2.27$ & $22.62^{\mathrm{a}} \pm 2.19$ & $30.11^{b} \pm 3.01$ & $25.82^{\mathrm{a}} \pm 2.01$ & $31.97^{b} \pm 1.23$ \\
\hline & Ear & $17.72^{\mathrm{a}} \pm 0.05$ & $17.52^{\mathrm{a}} \pm 0.42$ & $17.52^{\mathrm{a}} \pm 1.36$ & $21.69^{\mathrm{b}} \pm 2.28$ & $28.79^{\mathrm{a}} \pm 1.68$ & $30.84^{\mathrm{b}} \pm 2.93$ \\
\hline
\end{tabular}

- Different superscript $(a, b)$ in a row at particular THI indicate significant $(\mathrm{P}<0.05)$ difference.

lose the heat from the body. Higher sweating rate, vasodilatation with increased blood flow to skin surface is the physiological responses that are associated with heat stress in dairy animals (West, 1999). During heat stress, thermoregulation requires higher blood flow to the skin surfaces where evaporation occurs. These adjustments in the partitioning of water and blood flow away from energy metabolism to thermoregulation would act to reduce the metabolism of production. The results of the present study indicated increase in the skin blood flow at different body regions with the increase of THI, which suggests that at higher THI, animals divert greater blood volume to skin for heat dissipation to maintain homeostasis.

\section{Milk yield}

The milk yield of Tharparkar and Karan Fries cows were recorded prior to exposure to different climatic chamber conditions/THI and results have been presented in Fig. 1. The initial milk yield was $7.41 \pm 1.20 \mathrm{lit} / \mathrm{day}$ and $15.58 \pm 3.33$ litre/day in Tharparkar and Karan Fries cows respectively. After exposing these animals at THI of 72.2, the milk yield was almost same in Tharparkar cows, whereas the milk yield of Karan Fries cows was decrease to $14.37 \pm 3.45$ from $15.58 \pm 3.33$ litre/day. This decrease in milk yield of Karan Fries cows indicating that the THI 72.2 is stressful to this breed. Singh and Upadhyay (2009) also reported that THI above 70 is stressful for crossbred cattle. Hill and Wall (2015) also reported a decrease in milk yield i.e. $230 \mathrm{gm} /$ day/cow for each unit rise of THI above 66 in Holstein Friesian cows. The reason for reduction in milk yield is the negative energy balance as the animal try to maintain homeostasis to avoid hyperthermia (Renna et al., 2010). Keeping the initial values of milk yield constant i.e $7.41 \pm 1.20 \mathrm{lit} /$ day and $15.58 \pm 3.33$ litre/day in Tharparkar and Karan Fries cows respectively. The decrease in milk yield was calculated per unit increase in THI above 72.2 , the decrease in milk yield at THI of 85.3 was 


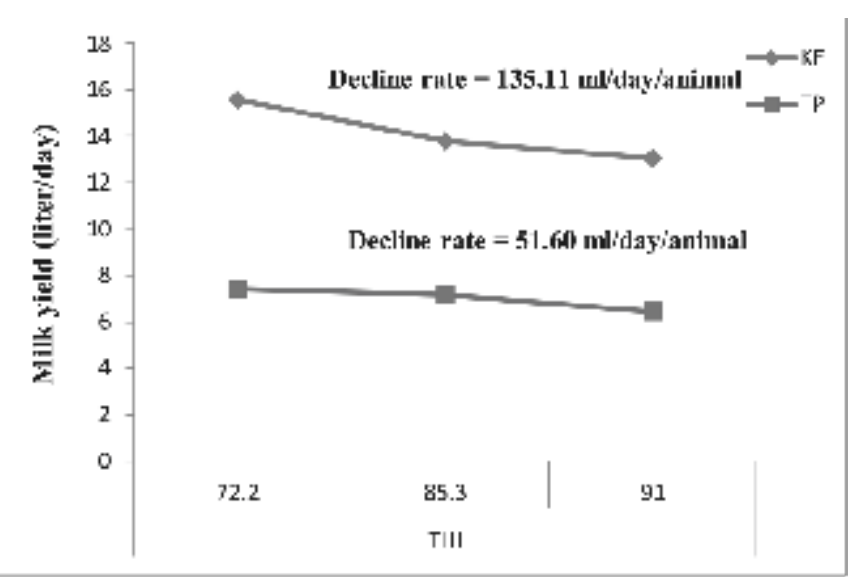

Fig. 1: Effect of different THI on milk yield of Karan Fries and Tharparkar cows exposed to controlled climatic chamber

$136.64 \mathrm{ml} /$ unit in Karan Fries and $19.08 \mathrm{ml} /$ unit in Tharparkar cows. Whereas the decrease in milk yields at higher THI i.e. 91 the decrease was $135.11 \mathrm{ml} /$ unit in Karan Fries and 51.60 $\mathrm{ml} /$ unit in Tharparkar cows. Bouraoui et al. (2002) reported a drop of milk production by $410 \mathrm{~g} / \mathrm{cow} /$ day for each point increase in the value of THI beyond 69 in the Mediterranean climatic. Bernabucci et al. (2010) also reported a reduction of milk yield@200 g/day/ cow with every unit increase in THI beyond 72. The higher drop in milk yield of Karan Fries cows than Tharparkar might be due to more susceptibility of this breed to higher THI.

\section{CONCLUSIONS}

Physiological responses viz. respiration rate, rectal temperature, pulse rate, skin temperature and blood flow give an immediate response to climatic stress and thus to the level of comfort of the animal. Therefore, these parameters are important in measuring the comfort level of the animals and thus the production potential of the animals. Karan Fries cows (crossbred) have poor heat tolerance capacity compared to indigenous (Tharparkar) cattle, and are more prone to heat stress due to lesser number of sweat glands, dark body colour and lower surface area/ unit of body weight. Skin blood flow in different body regions and physiological responses were higher at higher THI (85.3 and 91) compared to comfortable THI (72.2), which may suggest that during higher THI, animals divert their blood flow to periphery to maintain homeostasis instead of production. Therefore, we may conclude that both higher THI are stressful to both breeds of cattle, which also affected milk yield adversely. However, the both higher THI are more stressful to crossbred (Karan Fries) cows compared to tropical breed (Tharparkar) of cattle. Study provides insight for developing climate smart strategies to ameliorate the adverse impact of heat stress for improving the welfare and efficiency of milk production of bovine at higher
THI (91.0).

\section{ACKNOWELDEGEMENT}

The authors would like to thank the Director of NDRI, Karnal for providing the necessary facilities for the conducting research work. The necessary fund received from NICRA project for the experiment is highly acknowledged.

\section{REFERENCES}

Bernabucci, U., Lacetera, N., Baumgard, L.H., Rhoads, R.P., Ronchi, B. and Nardone, A. (2010). Metabolic and hormonal acclimation to heat stress in domesticated ruminants. Animal, 4(7): 1167-1183.

Bhan, C., Singh S.V., Hooda, O.K., Upadhyay, R.C., Beenam and Mangesh, V. (2012). Influence of temperature variability on physiological, hematological and biochemical profile of growing and adult Sahiwal cattle. J. Environ. Res. Develop., 7(2A): 986-94.

Bhan, C., Singh, S.V., Upadhyay, R.C., Hooda, O.K. and Beenam. (2013). Impact of temperature variability on physiological, haematological and biochemical profile of growing and adult Murrah buffaloes. $J$. Agrometeorol., 15: 146-52.

Bouraoui, R., Lahmar, M., Majdoub, A., Djemali, M. and Belyea, R. (2002). The relationship of temperaturehumidity index with milk production of dairy cows in a Mediterranean climate. Animal Res., 51(6): 479-491.

Cardoso, C.C., Lima, F.G., Fioravanti, M.C.S., do Egito, A.A., e Silva, F.G., de.p., Tanure, C.B., Peripolli, V., and McManus, C. (2016). Heat Tolerance in Curraleiro PeDuro, Pantaneiro and Nelore Cattle Using Thermographic Images. Animals, 6(2): 9.

Church, J.S., Hegadoren, P.R., Paetkau, M.J., Miller, C.C., Regev-Shoshani, G., Schaefer, A.L. and SchwartzkopfGenswein, K.S. (2014). Influence of environmental factors on infrared eye temperature measurements in cattle. Res. Vet. Sci., 96(1): 220-226.

Gaughan, J.B., Holt, S.M., Hahn, G.L., Mader, T.L. and Eigenberg, R. (2000). Respiration rate-is it a good measure of heat stress in cattle? Asian Australas. J. Animals Sci., 13: 329-332

Guyton, A. and Hall, J. (2006). Body temperature, temperature regulation and fever. Textbook of Medical Physiology. $11^{\text {th }}$ ed. Elsevier Inc, Philadelphia. pp 889-900.

IPCC (2014). Degrees of change: the IPCC's projections for 
future temperature rise.

Hill, D.L. and Wall, E. (2015). Dairy cattle in a temperate climate: The effects of weather on milk yield and composition depend on management. Animal, 9(1): 138-149.

Hoffmann, G., Schmidt, M., Ammon, C., Rose-Meierhöfe,r S., Burfeind, O., Heuwieser, W. and Berg, W. (2013). Monitoring the body temperature of cows and calves using video recordings from an infrared thermography camera. Vet. Res. Commun., 37(1):91-99.

Kotrba, R., Kný žkova, I., Kunc, P. and Bartos, L. (2007). Comparison between the coat temperature of the eland and dairy cattle by infrared thermography. $J$. Thermal Biol., 32(6): 355-59.

Kumar, S., Singh, S.V. and Soren, S. (2017). Physiological responses and in-vitro volatile fatty acid production in cattle. Int. J. Curr. Microbiol. Appl. Sci., 6(2): 86-94.

Marai, I.F.M., El-Darawany, A.A., Fadiel, A. and AbdelHafez, M.A.M. (2007). Physiological traits as affected by heat stress in sheep- A review. Small Ruminant Res., 71(1-3): 1-12.

Maibam, U., Hooda, O.K., Sharma, Ph. S., Singh, S.V., Mohanty, A.K. and Upadhyay R.C. (2017). Seasonal variation in HSP70 expression and oxidative stress in skin of zebu (Tharparkar) and crossbred (Karan Fries) cattle under tropical climate. Biol. Rhythm Res., 48(4): 647-661.

National Research Council (2001). Nutrient requirements of dairy cattle: seventh revised edition, 2001. Washington, DC: The National Academic Press.

Renna, M.C., Lussiana, V., Malfatto, A., Mimosi and Battaglini L.M. (2010). Effect of exposure to heat stress conditions on milk yield and quality of dairy cows grazing on Alpine pasture. Proceedings of the 9th European IFSA Symposium on Climate Change:
Agriculture, Food Security and Human Health, July 47,2010, Vienna, Austria, pp: 1338-1348.

Roberto, J.V.B. and De Souza, B.B. (2014). Use of infrared thermography in veterinary medicine and animal production. J. Animal Behavior Biomet., 2(3): 73-84.

Sajjanar, B., Deb, R., Singh, U., Kumar, S., Brahmane, M.P., Nirmale, A.V., Bal, S.K. and Minhas, P.S. (2015). Identification of SNP in HSP90AB1 and its association with relative thermotelerance and milk production traits in Indian dairy cattle. Animal Biotech. 26(1): 4550.

Singh, R. and Singh, S.V. (2006). Circadian changes in peripheral temperature and physiological responses under solar exposure and shed during summer in Karan Fries heifers. Ind. J. Ani. Sci., 76(8): 605-60.

Singh, S.V. and Upadhyay, R.C. (2009). Impact of temperature rise on physiological function, thermal balance and milk production of lactating Karan Fries and Sahiwal cows. Ind. Vet. J., 86(2): 141-44.

Singh, A.K., Devi, R., Kumar, Y., Kumar P. and Upadhyay, R.C. (2014). Physiological Changes and Blood Flow in Murrah Buffaloes during Summer and Winter Season. J. Buffalo Sci., 3(2):1-7.

Vaidya, M.M., Kumar, P. and Singh, S.V. (2012). Circadian changes in heat storage and heat loss through sweating and panting in Karan Fries cattle during different seasons. Biol. Rhythm Res., 43:137-146.

Velagala, C. Sekhar Naidu. and Singh, S.V. (2018). Expression of deiodinase 2(DIO2) and integrin alpha 9 (ITGA9) genes as indicators' of adaptability and their relationship with physio-biochemical parameters in Tharparkar and Karan Fries heifers during different seasons. Indian J. Animal Sci., 88 (9): 1030-1036.

West, J.W. (1999). Nutritional strategies for managing the heat stressed dairy cow. J. Animal Sci., 77 (Suppl. 2):21-35. 